Marquette University

e-Publications@Marquette

$1-1-2003$

Japanese Attitudes toward American Business Involvement in Japan: an Empirical Investigation Revisited

Syed H. Akhter

Marquette University, syed.akhter@marquette.edu

Toshikazu Hamada

Sophia University

Accepted version. Journal of Consumer Marketing, Vol. 20, No. 6 (2003): 526-535. DOI. (C) 2003

Emerald. Used with permission. 


\title{
Japanese attitudes toward American business involvement in Japan: an empirical investigation revisited
}

\author{
Syed H. Akhter 1 \\ Department of Marketing, Marquette University \\ Milwaukee, WI \\ Toshikazu Hamada 2 \\ Department of Economics, Sophia University \\ Tokyo, Japan
}

\begin{abstract}
:
Generation Xers in Japan continue to draw increasing attention not only because they constitute a promising segment for many products and services but also because they are expected to play a critical role in shaping their country's political and economic relations with other countries. This paper examines their attitudes toward US products, businesses, and government. It also examines their behavioral intentions and their expectations of their government in terms of managing American business involvement in Japan. Findings and implications are presented.
\end{abstract}

Keywords: Business development, Perception, Attitudes, Japan

\section{Understanding attitudes}

There are four significant reasons for understanding attitudes, expectations, and behavioral intentions of Japanese Generation X toward US business involvement in Japan. First, the group meets the criteria of a viable market segment -it is identifiable, measurable, reachable, and profitable. Second, the group is expected to play a significant economic and political role in the country. Third, existing 
research indicates that the group exhibits attitudinal and behavioral patterns that are different from other groups. Fourth, the USA and Japan, besides being the two largest economies in the world, are also major trading partners with vital economic interests in each other.

\section{Generation $\mathbf{X}$}

The paper replicates a study conducted nine years ago at a major university in Tokyo, Japan with the goal of determining whether attitudes, expectations, and behavioral intentions of Generation X have changed over time (Akhter and Hamada, 1995). Contextual information is provided to establish the significance of bilateral relations between the USA and Japan. To achieve the goals, we have divided this paper into four sections. In the first section, we compare the economies of the USA and Japan in terms of gross domestic product, exports, and foreign direct investments, and show the importance of bilateral trade and investment relations between the two countries. In the second section, we review the literature and give reasons for examining attitudes, expectations, and behavioral intentions of Japanese Generation X. In the third section, we discuss research method and present findings. In the fourth, we present strategic business and marketing implications.

\section{US and Japanese economies}

The USA and Japan are the two largest economies in the world. In 2001, the US gross national income (GNI) was $\$ 9.8$ trillion and Japan's was $\$ 4.5$ trillion. The per capita GNI in the USA was $\$ 34,280$ and in Japan $\$ 35,610$ (World Bank, 2003). The USA and Japan are also major global players. In 1990, for example, the USA exported $\$ 394$ billion and imported $\$ 517$ billion of merchandise, while Japan exported $\$ 288$ billion and imported $\$ 235$ billion. In 2001, the USA increased its exports to $\$ 731$ billion and imports to $\$ 1.2$ trillion. Comparatively, Japan increased its exports to $\$ 403$ billion and imports to $\$ 349$ billion (World Bank, 2003).

\section{Foreign direct investments}

The USA and Japan also play a major role in foreign direct investments (FDI) as both the source and destination of FDI. However, US involvement in FDI is far more extensive than that of Japan's. In

Journal of Consumer Marketing, Vol 20, No. 6 (2003): pg. 526-535. DOI. This article is (c) Emerald and permission has been granted for this version to appear in e-Publications@Marquette. Emerald does not grant permission for this article to be further copied/distributed or hosted elsewhere without the express permission from Emerald. 
1980 , for example, the total inward stock of FDI in the US was $\$ 83$ billion, increasing to $\$ 1.08$ trillion by 1999 . Comparatively, the total inward stock of FDI in Japan was $\$ 3$ billion in 1980 , increasing to $\$ 38.8$ billion by1999. The total outward US stock of FDI in 1980 was $\$ 220$ billion, increasing to $\$ 1.13$ trillion by 1999 . Comparatively, the total outward stock of Japan's FDI in 1980 was $\$ 19.6$ billion, increasing to $\$ 292.8$ billion by1999 (World Bank, 2003).

\section{US and Japan trade and investment relations}

The above data highlight the significance of the USA and Japan in global trade and investment. The two countries are also major trading partners, relying on each other's capital and product markets for achieving economic growth and development. Japanese and US firms over the last three decades have invested heavily in each other's markets to exploit growing business opportunities and to consolidate market positions. In 2001, for example, the USA foreign direct investment position in Japan was $\$ 64$ billion on a historical cost basis, and that of Japan in the USA was $\$ 159$ billion.

\section{Trade surplus}

Japan's massive FDI in the USA have been spurred by increasing exports and bilateral trade surplus with the USA. Japan's exports to the USA in 1985, for example, were a little over $\$ 72$ billion, whereas USA exports to Japan were around $\$ 22$ billion. By2001 Japan increased its exports to the USA to $\$ 129$ billion while USA exports to Japan increased to $\$ 57$ billion (International Monetary Fund, 2002). Japan's exports to the USA are approximately twice that of USA to Japan. However, on a per capita basis, both the USA and Japan import roughly the same amount from each other. Notwithstanding this equality, it is the overall US trade deficit with Japan that many in the USA find unacceptable.

\section{US and Japan attitudinal relations}

Of the many reasons given for the persistent US trade deficit with Japan, the one commonly held by many in the USA is that unfavorable Japanese attitudes toward US products coupled with unfair trade practices create insurmountable non-tariff barriers for US products in Japan. These attitudinal barriers are viewed as more inimical to the marketing of US products in Japan than the official tariff

Journal of Consumer Marketing, Vol 20, No. 6 (2003): pg. 526-535. DOI. This article is (C) Emerald and permission has been granted for this version to appear in e-Publications@Marquette. Emerald does not grant permission for this article to be further copied/distributed or hosted elsewhere without the express permission from Emerald. 
barriers. Business Week (1989) reported that 68 per cent of those polled in the US thought that unfair trade barriers in Japan create trouble for US products in Japan. In yet another poll, 65 per cent of Americans believed that Japan unfairly restricts the sale of US goods (Smith, 1990). What is interesting to note is that the Japanese share similar views about the USA. They also claim that the US business environment is not particularly hospitable for Japanese businesses, citing examples of negative reactions in the US to their investments and marketing success.

\section{US and Japan country-of-origin studies}

International marketing scholars have produced an extensive body of literature on consumers' response to foreign firms and products. This corpus of research, generally classified as country-oforigin research, can conceptually be divided into two categories: one that attempts to model the relevance of country-of-origin construct in explaining some criterion variables, and the other that attempts to explore people's attitudes and behavior toward products from different countries. As this paper attempts to add to the second stream of research, we review only those studies that focus on the US and Japan. However, before reviewing this body of literature, we point out some of the significant findings from the first stream of research to establish the salience of the country-of-origin concept.

Country-of-origin

Findings indicate that consumers use a product's country-oforigin information to make various types of purchase-related decisions. When, for example, explicit product information is absent, consumers use made-in labels as a "shortcut" to determine product attributes and avoid unnecessary information processing (Johansson, 1989) or to predict product quality (Reierson, 1967). Findings also indicate that country-of-origin information affect product evaluation and preference. For example, consumers tend to have a more positive image of products from advanced economies than of products from less developed economies (Gaedeke, 1973; Schooler, 1965). In addition, some consumers tend to avoid products from one country while preferring those from others (Johansson and Nebenzahl, 1987). Tse and Gorn (1993), on the basis of empirical results, note that even in

Journal of Consumer Marketing, Vol 20, No. 6 (2003): pg. 526-535. DOI. This article is (c) Emerald and permission has been granted for this version to appear in e-Publications@Marquette. Emerald does not grant permission for this article to be further copied/distributed or hosted elsewhere without the express permission from Emerald. 
the era of globalization, the construct of country-of-origin remains salient in explaining consumer product evaluation.

Findings indicate that consumers not only evaluate and respond differently to products from developed and less developed economies, but also to products originating from developed economies. Nagashima (1970) in a pioneering study examined US and Japanese businessmens' attitudes toward products from five developed economies (USA, Japan, France, England, and Germany) and found that product ratings and purchase preferences were different. For example, while most Japanese businessmen rated US made products more reliable, more technically advanced, more inventive than Japanese products, and superior in careful and meticulous workmanship, only a small fraction of them, 3 per cent, selected US products as their first choice. In contrast, US businessmen rated US products better than Japanese products on such attributes as reliability, technical advancement, and workmanship, but did not select Japanese products at all as their first choice. His findings indicate that purchase decisions of Japanese and US businessmen were influenced not only by intrinsic product attributes but also by extrinsic factors.

Overall results

In a follow up study, seven years later, Nagashima (1977) found that while US products fell into the last place in terms of careful and meticulous workmanship, Japanese products moved up in their ratings. In summarizing the change, Nagashima (1977, p. 98) noted that "the US image had declined considerably". In yet another study, Kamins and Nagashima (1995) examined US and Japanese perceptions of Japanese and US products using the same variables that Nagashima used in 1977. The overall results indicate that while the image of US products had been declining both in the US and in Japan, the image of Japanese products had been improving.

Other studies that have examined US and Japanese attitudes include Chiesl and Knight (1981), Maronick (1995), and Nishina (1990). Nishina (1990), for example, conducted an extensive study and found that Japanese consumers associated the USA with advanced industrial technology, agricultural products, and products of high function and quality. Maronick (1995, p. 29) investigated the perception of "made in USA claims" in a sample of US consumers and granted for this version to appear in e-Publications@Marquette. Emerald does not grant permission for this article to be further copied/distributed or hosted elsewhere without the express permission from Emerald. 
found, among other things, that the addition of the "made in USA" claim was not "an automatic cue for more positive beliefs about the product or its quality." In their study of purchasing directors drawn from the Japanese Company Handbook, Chiesl and Knight (1981) found that although the respondents held favorable attitudes toward US product innovativeness, they thought that US firms did not modify their products to suit Japanese markets.

\section{Different segments}

The existing studies have contributed to our understanding of attitudes and intentions of different segments of US and Japanese people. Our goal is to add another segment, Generation X, to these segments to enhance our understanding of attitudes, expectations, and behavioral intentions. This study, as a follow up of the earlier study, examines Japan's Generation $X$ beliefs about American products, attitudes toward US firms, perception of US government, expected role of Japanese government, and behavioral intentions. By examining changes in these factors over time, this study adds to the cross-national attitudinal literature and provides strategic guidance to business and public policy decision makers.

\section{Method and findings}

\section{Survey instrument and subjects}

A survey questionnaire was translated into Japanese from English following the recommended translation method for conducting cross national research. For each statement in the questionnaire, subjects were asked to indicate their agreement or disagreement on a five-point Likert scale, anchored by strongly disagree and strongly agree. The 134 subjects who completed the questionnaire were students at a large university in Tokyo, Japan who meet the age criterion of Generation X. Furthermore, because of their income and education levels, these subjects can be considered members of what Yankelovich Partners survey identify as "Yup and Comers" group of Generation X (Benezra, 1995).

Journal of Consumer Marketing, Vol 20, No. 6 (2003): pg. 526-535. DOI. This article is (C) Emerald and permission has been granted for this version to appear in e-Publications@Marquette. Emerald does not grant permission for this article to be further copied/distributed or hosted elsewhere without the express permission from Emerald. 
NOT THE PUBLISHED VERSION; this is the author's final, peer-reviewed manuscript. The published version may be accessed by following the link in the citation at the bottom of the page.

\section{Research findings}

Interpreting results

Findings are presented in Tables I-V. In each table, the percentage response number on the left is from the last survey and on the right from the current survey. For comparing and interpreting the results of the two surveys we combine the two extreme responses. We sum the two categories "strongly disagree" and "disagree" and likewise we sum "strongly agree" and "agree". For example, with the statement "US products are the best in the Japanese market" 31.1 per cent of respondents "strongly disagreed" with the statement in the last survey compared to 13.6 per cent in the current survey. And 52.2 per cent "disagreed" in the last survey compared to 65.2 per cent in the current. Thus, a total of 83.3 per cent of respondents either strongly disagreed or disagreed with the statement in the last survey compared to 78.8 per cent in the current survey (please see Table I).

\section{US products}

Comparatively, the results are mixed. The positive signs are that fewer respondents in this survey either disagreed or strongly disagreed with the statement that US products are the best in the Japanese market (78.8 per cent versus 83.3 per cent), more respondents either agreed or strongly agreed with the statement that US products are a better deal for the money than non-US products (21.2 per cent versus 12 per cent), and fewer respondents either agreed or strongly agreed with the statement that US products require more maintenance than Japanese products (37.9 per cent versus 49.7 per cent). In contrast, the percentage of respondents who either agreed or strongly agreed with the statement that US products break down more often than Japanese products increased from 45.3 per cent to 62.9 per cent, and the percentage of respondents who either disagreed or strongly disagreed with the statement that US products perform better than Japanese products increased from 55.9 per cent to 75.7 per cent. Overall, the evaluations of American products continue to be unfavorable. The respondents, in general, believe that US products are not the best in Japanese markets, that they break down more often than Japanese products, and that they do not perform better than Japanese products (see Table I for a complete breakdown of responses).

Journal of Consumer Marketing, Vol 20, No. 6 (2003): pg. 526-535. DOI. This article is (C) Emerald and permission has been granted for this version to appear in e-Publications@Marquette. Emerald does not grant permission for this article to be further copied/distributed or hosted elsewhere without the express permission from Emerald. 
NOT THE PUBLISHED VERSION; this is the author's final, peer-reviewed manuscript. The published version may be accessed by following the link in the citation at the bottom of the page.

\section{US firms}

\section{Significant difference}

A significant difference between the two surveys was found in beliefs regarding US firms. There was an increase in the percentage of respondents who either agreed or strongly agreed with the statements that US businesses want to establish monopoly power in Japan (from 41.6 per cent to 68.1 per cent), that they are ruthless competitors (from 30.5 per cent to 57.9 per cent), that they are increasing their influence over Japanese officials (from 41.6 per cent to 59.7 per cent), and that they treat their employees in the US better than their employees in Japan (from 23 per cent to 28.4 per cent). However, US executives fared better. They were seen as caring more for their companies than for themselves (from 7.5 per cent to 24.1 per cent), and sacrificing short-term goals for long-term goals (from 8.7 per cent to 32.4 per cent). In contrast, there was an increase in the percentage of respondents who either disagreed or strongly disagreed with the statements that US businesses operating in Japan keep the interest of Japan uppermost (from 69 per cent to 78.9 per cent), and that US businesses give more to the Japanese economy than they take from it (from 38.5 per cent to 58.2 per cent). With the later statement, however, the percentage of respondents who either agreed or disagreed also increased from 11.8 per cent to 17.2 per cent. Overall, the evaluations of US firms cannot be considered favorable especially with regard to their contributions to the Japanese society and their influence over Japanese public officials (see Table II for a complete breakdown of responses).

\section{US government}

\section{Two surveys}

There was a significant difference in the perception of US government between the two surveys. There was an increase in the percentage of respondents who either agreed or strongly agreed with the statements that the US government does not allow Japanese firms to operate freely in the USA (from 34.8 per cent to 50.8 per cent), that the US government helps US firms more than the Japanese government helps Japanese firms (from 24.2 per cent to 59.7 per cent), and that the US government unfairly supports US businesses to

Journal of Consumer Marketing, Vol 20, No. 6 (2003): pg. 526-535. DOI. This article is (C) Emerald and permission has been granted for this version to appear in e-Publications@Marquette. Emerald does not grant permission for this article to be further copied/distributed or hosted elsewhere without the express permission from Emerald. 
gain a competitive advantage in the Japanese market increased ( 25.4 per cent to 29.8 per cent). Views regarding the influence of foreign lobbyists on the US government did not change much. However, the respondents overwhelmingly either disagreed or strongly disagreed with the statement that the US government does not keep the interest of the USA first. The percentage changed from 61.5 per cent to 92.6 per cent (see Table III for a complete breakdown of responses).

\section{Japanese government}

There was a significant difference in the expected role of the Japanese government. For example, there was an increase in the percentage of respondents who either agreed or strongly agreed with the statements that the Japanese government should set a limit on US investments (from 10.5 per cent to 43.2 per cent), that it should not allow US firms to send profits back to the US (from 6.2 per cent to 14.9 per cent), that it should control US business involvement in all sectors of the Japanese economy (from 17.4 per cent to 35.1 per cent), that it should have a restrictive set of rules for US businesses (from 19.3 per cent to 56.7 per cent), that it should not buy US products (from 3.1 per cent to 10.5 per cent), and that it should set an upper limit on market shares of US companies (from 20.5 per cent to 52.2 per cent). Furthermore, there was a decrease in the percentage of respondents who either agreed or strongly agreed (from 31.7 per cent to 26.9 per cent) with the statement that the Japanese government should stay out of the affairs of US businesses. Overall, the expectation is that of more governmental involvement in managing American businesses in Japan (see Table IV for a complete breakdown of responses).

\section{Behavioral intentions}

\section{Behavioral intentions}

The results were mixed for behavioral intentions. There was an increase in the percentage of respondents who either disagreed or strongly disagreed with the statements that they did not intend to buy US products (from 62.1 per cent to 76.1 per cent), that they intended to recommend that their friends only buy Japanese products (from 77.6 per cent to 88.8 per cent), that they intended to discourage their friends from buying US products (from 80.1 per cent to 82.9 per cent),

Journal of Consumer Marketing, Vol 20, No. 6 (2003): pg. 526-535. DOI. This article is (c) Emerald and permission has been granted for this version to appear in e-Publications@Marquette. Emerald does not grant permission for this article to be further copied/distributed or hosted elsewhere without the express permission from Emerald. 
and that they intended not to work for a US company (from 48.5 percent to 61.9 per cent). However, with the statement that they intended not to support the idea of a US company doing business in Japan, the percentage of respondents who either disagreed or strongly disagreed declined from 54 per cent to 29.8 per cent. In addition, there was an increase in the percentage of respondents who either agreed or strongly agreed with the statements that they intended to buy US products only if Japanese products are not available (from 7.5 per cent to 26.1 per cent), that they intended to discourage Japanese scientists from selling their technology to US firms (from 6.2 per cent to 36.6 per cent), and that they intended to discourage Japanese businesses from selling their technology to US firms (from 8.7 per cent to 32.9 per cent). Overall, while the respondents, on the one hand, intend to buy American products and work for American companies, they also, on the other hand, intend to discourage their businesses and scientists from selling their technologies to American firms.

\section{Conclusions and strategic implications}

\section{Globalization and economic nationalism}

Globalization and economic nationalism, as two opposing forces, are channeling the flow of products, capital, technology, and services between countries. Spurred by technological developments and people's desire to seek new products and new markets, globalization has created both opportunities and threats for US firms. While making the world more interconnected and interdependent, globalization has also rekindled an old force, the force of economic nationalism. The leitmotif of this ideology is shaped by the belief that increasing international trade can adversely affect the socioeconomic and political climate of a country, especially of the disadvantaged sectors, and therefore should be pursued cautiously. How a country chooses to respond to globalization will be impacted by beliefs people hold regarding the effects of international trade on their society and their attitudes toward foreign firms, products, and the government.

The product related findings from this study provide important strategic implications for US firms in Japan. Japanese preference for local products, for example, is shaped by their belief in the overall superiority of their products. Thus, for US firms to succeed in Japan, a concerted effort is needed to improve product quality as well as its

Journal of Consumer Marketing, Vol 20, No. 6 (2003): pg. 526-535. DOI. This article is (c) Emerald and permission has been granted for this version to appear in e-Publications@Marquette. Emerald does not grant permission for this article to be further copied/distributed or hosted elsewhere without the express permission from Emerald. 
perception. In the long run, the success of US products in Japan will depend on how well they deliver value and satisfaction to consumers.

\section{Social system}

Regardless of its country of origin, when a firm starts its operations in a foreign country it becomes a part of the local social system. As such, its decisions can have an impact on the economic, social, and political lives of the people. For US firms doing business in Japan, it is thus important to see themselves as a part of the social system and meet the expectations of the people by becoming good corporate citizens. The US image is indeed a selling point worldwide. It also remains a vulnerable symbol in uncertain times. Firms, therefore, should attempt to strike a balance between their US identity and local responsiveness.

The overall perception of the US government in Japan is not favorable. In general, the view is that the US government intervenes on behalf of US firms and does not allow equal access to Japanese firms in the US market. This perception can persuade people to engage in actions that may not serve the interests of US firms. Overwhelmingly, the Japanese believe that the US government acts in the interest of the US first. Although this is as it should be, the significant change in Japanese perception in the last ten years suggests the need to clearly communicate the goals and objectives of the US government.

\section{Agreements}

There is a marked shift in the expected role of the Japanese government in managing US businesses. Although a government is constrained by bilateral and multilateral agreements, it can, none the less, take actions to regulate the activities of foreign firms (Akhter et al., 2003). When citizens expect greater governmental involvement in managing foreign businesses, the government may find it difficult to ignore the demand. This can have serious ramifications for bilateral trade relations between the two countries.

Although the respondents find American products lacking in different attributes in relation to Japanese products, they do not show any inclination not to buy American products. This is a positive sign that need to be exploited. Two changes, however, are noticeable, an

Journal of Consumer Marketing, Vol 20, No. 6 (2003): pg. 526-535. DOI. This article is (C Emerald and permission has been granted for this version to appear in e-Publications@Marquette. Emerald does not grant permission for this article to be further copied/distributed or hosted elsewhere without the express permission from Emerald. 
increase in the intention to purchase US products only if Japanese products are not available and an increase in the desire to persuade scientists and businesses not to sell Japanese technology and businesses to US firms. A public relation campaign that highlights the contributions of US firms to the Japanese economy needs to be made an integral part of promotional campaigns. Toyota and Honda have successfully followed this strategy in the USA.

\section{References}

Akhter, S.H. and Hamada, T. (1995), "Japanese attitudes toward American business involvement in Japan: an empirical investigation", Journal of Consumer Marketing, Vol. 12 No. 3, pp. 56-62.

Akhter, S.H., Kim, D. and Hosseini, J. (2003), "The influence of economic nationalism and product quality on behavioral intentions: an empirical investigation", Journal of Global Business, Spring, pp. 75-83.

Benezra, K. (1995), "Don't mislabel Gen X", Brandweek, Vol. 36 No. 20, 15 May, pp. 32-4. Business Week (1989), "What Americans think of Japan Inc.", 7 August, p. 51.

Chiesl, N.E. and Knight, L.L. (1981), "Japanese buyers' attitudes toward US supply sources", Industrial Marketing Management, Vol. 10, October, pp. 243-51.

Gaedeke, R. (1973), "Consumer attributes towards products 'made in' developing countries", Journal of Retailing, Vol. 49, Summer, pp. 1324.

International Monetary Fund (2002), Direction of Trade Statistics Yearbook, IMF, Washington, DC, September.

Johansson, J.K. (1989), "Determinants and effects of the use of 'made in' labels", International Marketing Review, Vol. 6 No. 1, pp. 47-58.

Johansson, J.K. and Nebenzahl, I.D. (1987), "Country-of-origin, social norms, and behavioral intentions", in Cavusgil, S.T. (Ed.), Advances in International Marketing, Vol. II, JAI Press, Greenwich, CT.

Kamins, M.A. and Nagashima, A. (1995), "Perceptions of products made in Japan versus those made in the United States among Japanese and American executives: a longitudinal perspective", Vol. 12 No. 1, pp. 49-68.

Journal of Consumer Marketing, Vol 20, No. 6 (2003): pg. 526-535. DOI. This article is @ Emerald and permission has been granted for this version to appear in e-Publications@Marquette. Emerald does not grant permission for this article to be further copied/distributed or hosted elsewhere without the express permission from Emerald. 
NOT THE PUBLISHED VERSION; this is the author's final, peer-reviewed manuscript. The published version may be accessed by following the link in the citation at the bottom of the page.

Maronick, T.J. (1995), "An empirical investigation of consumer perceptions of 'made in USA' claims", International Marketing Review, Vol. 12 No. 3, pp. 15-30.

Nagashima, A. (1970), "A comparison of Japanese and US attitudes toward foreign products", Journal of Marketing, Vol. 34, January, pp. 68-74.

Nagashima, A. (1977), A comparative 'made in' product image survey among Japanese businessmen", Journal of Marketing, Vol. 41, July, pp. 97100.

Nishina, S. (1990), "Japanese consumers: introducing foreign products/brands into the Japanese market", Journal of Advertising Research, April-May, pp. 35-45.

Reierson, C. (1967), "Attitude changes toward foreign products", Journal of Marketing Research, November, pp. 385-7.

Schooler, R.D. (1965), "Product bias in the central American common market", Journal of Marketing Research, Vol. 2, November, pp. 394-7.

Smith, L. (1990), "Fear and loathing of Japan", Fortune, 26 February, pp. 5060.

Tse, D.K. and Gorn, G.J. (1993), "An experiment on the salience of countryof-origin in the era of global brands", Journal of International Marketing, Vol. 1 No. 1, pp. 57-76.

World Bank (2003), World Development Indicators 03, The World Bank, Washington, DC.

\section{Notes}

- ${ }^{1}$ Chairman and Associate Professor, Department of Marketing, Marquette University, Milwaukee, Wisconsin, USA

- 2 Professor, Department of Economics, Sophia University, Tokyo, Japan

Journal of Consumer Marketing, Vol 20, No. 6 (2003): pg. 526-535. DOI. This article is (C Emerald and permission has been granted for this version to appear in e-Publications@Marquette. Emerald does not grant permission for this article to be further copied/distributed or hosted elsewhere without the express permission from Emerald. 
NOT THE PUBLISHED VERSION; this is the author's final, peer-reviewed manuscript. The published version may be accessed by following the link in the citation at the bottom of the page.

\section{Appendix}

Table I Attitudes toward US products

\begin{tabular}{|l|l|l|l|l|l|l|l|r|r|}
\hline \multicolumn{10}{|c|}{ Response Percentage } \\
\hline
\end{tabular}

Table 2

Attitudes toward US firms

\begin{tabular}{|c|c|c|c|c|c|c|c|c|c|c|}
\hline \multicolumn{11}{|c|}{ Response Percentage } \\
\hline & \multicolumn{2}{|c|}{$\begin{array}{l}\text { Strongly } \\
\text { disagree }\end{array}$} & \multicolumn{2}{|c|}{ Disagree } & \multicolumn{2}{|c|}{ Neutral } & \multicolumn{2}{|c|}{ Agree } & \multicolumn{2}{|c|}{ Strongly Agree } \\
\hline & Last & Current & Last & Current & Last & Current & Last & Current & Last & Current \\
\hline Beliefs & survey & survey & survey & survey & survey & survey & survey & survey & survey & survey \\
\hline \multicolumn{11}{|c|}{ US businesses want to establish monopoly power in the Japanese market } \\
\hline & 0.6 & 2.3 & 25.5 & 9.1 & 32.3 & 20.5 & 36.0 & 54.5 & 5.6 & 13.6 \\
\hline \multicolumn{11}{|c|}{ US businesses are ruthless competitors } \\
\hline & 1.9 & 3.0 & 29.8 & 10.5 & 37.9 & 28.6 & 28.6 & 39.1 & 1.9 & 18.8 \\
\hline \multicolumn{11}{|c|}{ US executives care more for their companies than themselves } \\
\hline & 14.3 & 8.3 & 47.2 & 36.1 & 31.1 & 31.6 & 7.5 & 22.6 & 0.0 & 1.5 \\
\hline \multicolumn{11}{|c|}{ US businesses sacrifice short-term goals for long-term goals } \\
\hline & 15.5 & 3.8 & 33.5 & 18.0 & 42.2 & 45.9 & 6.8 & 30.1 & 1.9 & 2.3 \\
\hline \multicolumn{11}{|c|}{ US businesses operating in Japan keep the interest of Japan uppermost } \\
\hline & 23.0 & 33.8 & 46.0 & 45.1 & 23.0 & 13.5 & 5.6 & 6.0 & 1.9 & 1.5 \\
\hline \multicolumn{11}{|c|}{ US businesses give more to the Japanese economy than they take from it } \\
\hline & 6.8 & 7.5 & 31.7 & 50.7 & 49.7 & 24.6 & 10.6 & 15.7 & 1.2 & 1.5 \\
\hline \multicolumn{11}{|c|}{ US businesses are increasing their influence over Japanese government officials } \\
\hline & 0.6 & 0.7 & 14.3 & 13.4 & 43.5 & 26.1 & 36.0 & 48.5 & 5.6 & 11.2 \\
\hline \multicolumn{11}{|c|}{$\begin{array}{l}\text { US businesses treat their employees in the USA better than the Japanese companies treat their } \\
\text { employees in Japan }\end{array}$} \\
\hline & 8.7 & 6.7 & 22.4 & 23.9 & 46.0 & 41.0 & 21.1 & 23.9 & 1.9 & 4.5 \\
\hline
\end{tabular}

Journal of Consumer Marketing, Vol 20, No. 6 (2003): pg. 526-535. DOI. This article is @ Emerald and permission has been granted for this version to appear in e-Publications@Marquette. Emerald does not grant permission for this article to be further copied/distributed or hosted elsewhere without the express permission from Emerald. 
NOT THE PUBLISHED VERSION; this is the author's final, peer-reviewed manuscript. The published version may be accessed by following the link in the citation at the bottom of the page.

Table 3

Perception of US government

\begin{tabular}{|c|c|c|c|c|c|c|c|c|c|c|}
\hline \multicolumn{11}{|c|}{ Response percentage } \\
\hline & \multicolumn{2}{|c|}{$\begin{array}{l}\text { Strongly } \\
\text { disagree }\end{array}$} & \multicolumn{2}{|c|}{ Disagree } & \multicolumn{2}{|c|}{ Neutral } & \multicolumn{2}{|c|}{ Agree } & \multicolumn{2}{|c|}{ Strongly agree } \\
\hline & Last & Current & Last & Current & Last & Current & Last & Current & Last & Current \\
\hline Beliefs & survey & survey & survey & survey & survey & survey & survey & survey & survey & survey \\
\hline \multicolumn{11}{|c|}{ The US government does not allow Japanese firms to operate freely in the USA } \\
\hline & 5.0 & 3.7 & 29.2 & 23.9 & 31.1 & 21.6 & 27.3 & 39.6 & 7.5 & 11.2 \\
\hline \multicolumn{11}{|c|}{$\begin{array}{l}\text { The US government helps US firms more than the Japanese government helps Japanese firms to } \\
\text { conduct international business }\end{array}$} \\
\hline & 31.1 & 3.0 & 22.4 & 10.4 & 50.3 & 26.9 & 21.1 & 48.5 & 3.1 & 11.2 \\
\hline \multirow{2}{*}{\multicolumn{11}{|c|}{$\begin{array}{l}\text { The US government unfairly supports US businesses to gain a competitive advantage in the Japanese } \\
\text { market }\end{array}$}} \\
\hline & & & & & & & & 24.6 & 6.8 & 5.2 \\
\hline \multicolumn{11}{|c|}{ Unlike Japan, the US government is not influenced by foreign lobbyists } \\
\hline & 3.7 & 7.5 & 30.4 & 26.9 & 36.0 & 38.1 & 26.1 & 24.6 & 3.7 & 3.0 \\
\hline \multicolumn{11}{|c|}{ he US goverr } \\
\hline & 23.0 & 56.0 & 38.5 & 36.6 & 21.1 & 5.2 & 11.8 & 1.5 & 5.6 & 0.7 \\
\hline
\end{tabular}

Table 4

Role of Japanese government

\begin{tabular}{|c|c|c|c|c|c|c|c|c|c|c|}
\hline \multicolumn{11}{|c|}{ Response percentage } \\
\hline & \multicolumn{2}{|c|}{$\begin{array}{l}\text { Strongly } \\
\text { disagree }\end{array}$} & \multicolumn{2}{|c|}{ Disagree } & \multicolumn{2}{|c|}{ Neutral } & \multicolumn{2}{|c|}{ Agree } & \multicolumn{2}{|c|}{ Strongly agree } \\
\hline & Last & Current & Last & Current & Last & Current & Last & Current & Last & Current \\
\hline Beliefs & survey & survey & survey & survey & survey & survey & survey & survy & survey & survey \\
\hline \multicolumn{11}{|c|}{ The Japanese government should set a limit on US investments in Japan } \\
\hline & 9.9 & 5.2 & 53.4 & 21.6 & 26.1 & 29.9 & 9.3 & 32.8 & 1.2 & 10.4 \\
\hline \multicolumn{11}{|c|}{ The Japanese government should not allow US firms to send profits back to the USA } \\
\hline & 6.2 & 6.0 & 48.2 & 40.3 & & 38.8 & 5.6 & 11.9 & 0.6 & 3.0 \\
\hline \multicolumn{11}{|c|}{$\begin{array}{l}\text { The Japanese government should control US business involvements in all sectors of the Japanese } \\
\text { economy }\end{array}$} \\
\hline & 13.7 & 9.0 & 46.0 & 37.3 & 23.0 & 18.7 & 15.5 & 26.1 & 1.9 & 9.0 \\
\hline \multicolumn{11}{|c|}{ ment should have a restrictive set } \\
\hline & 10.6 & 4.5 & 39.1 & 19.4 & 30.4 & 19.4 & 16.8 & 46.3 & 2.5 & 10.4 \\
\hline \multicolumn{11}{|c|}{ The Japanese government should not buy US produ } \\
\hline & 31.1 & 19.4 & 52.8 & 48.5 & 11.2 & 21.6 & 3.1 & 9.0 & 0.0 & 1.5 \\
\hline \multicolumn{11}{|c|}{ compan } \\
\hline & 16.1 & 4.5 & 41.6 & 20.9 & 21.1 & 22.4 & 18.0 & 48.5 & 2.5 & 3.7 \\
\hline \multicolumn{11}{|c|}{ S businesses } \\
\hline & 6.8 & 6.7 & 27.3 & 38.8 & & 27.6 & 24.2 & 25.4 & 7.5 & 1.5 \\
\hline
\end{tabular}

Journal of Consumer Marketing, Vol 20, No. 6 (2003): pg. 526-535. DOI. This article is (C) Emerald and permission has been granted for this version to appear in e-Publications@Marquette. Emerald does not grant permission for this article to be further copied/distributed or hosted elsewhere without the express permission from Emerald. 
NOT THE PUBLISHED VERSION; this is the author's final, peer-reviewed manuscript. The published version may be accessed by following the link in the citation at the bottom of the page.

Table 5

Behavioral intentions

\begin{tabular}{|c|c|c|c|c|c|c|c|c|c|c|}
\hline \multicolumn{11}{|c|}{ Response percentage } \\
\hline & \multicolumn{2}{|c|}{$\begin{array}{l}\text { Strongly } \\
\text { disagree }\end{array}$} & \multicolumn{2}{|c|}{ Disagree } & \multicolumn{2}{|c|}{ Neutral } & \multicolumn{2}{|c|}{ Agree } & \multicolumn{2}{|c|}{ Strongly agree } \\
\hline & Last & Current & Last & Current & Last & Current & Last & Current & Last & Current \\
\hline Beliefs & survey & survey & survey & survey & survey & survey & survey & survey & survey & survey \\
\hline \multicolumn{11}{|c|}{ I do not intend to buy US products } \\
\hline & 14.3 & 38.8 & 47.8 & 37.3 & 32.3 & 15.7 & 3.7 & 7.5 & 1.2 & 0.7 \\
\hline \multicolumn{11}{|c|}{ I intend to recommend that my friends buy only Japanese products } \\
\hline & 24.8 & 54.5 & 52.8 & 34.3 & 18.0 & 9.0 & 1.9 & 1.5 & 1.2 & 0.7 \\
\hline \multicolumn{11}{|c|}{ I intend to buy US products only if Japanese products are not available } \\
\hline & 13.7 & 11.2 & 55.3 & 28.4 & 23.0 & 34.3 & 5.6 & 22.4 & 1.9 & 3.7 \\
\hline \multicolumn{11}{|c|}{ I intend to discourage my friends from buying US products } \\
\hline & 32.3 & 39.6 & 47.8 & 43.3 & 16.1 & 14.9 & 2.5 & 1.5 & 0.6 & 0.7 \\
\hline \multicolumn{11}{|c|}{ I intend not to work for a US company } \\
\hline & 13.7 & 23.1 & 34.8 & 38.8 & 32.9 & 26.9 & 11.2 & 8.2 & 6.2 & 3.0 \\
\hline \multicolumn{11}{|c|}{ I intend not to support the idea of a US company doing business in Japan } \\
\hline & 13.0 & 2.2 & 14.0 & 27.6 & 34.8 & 54.5 & 7.5 & 14.9 & 2.5 & 0.7 \\
\hline \multicolumn{11}{|c|}{ I intend to favor US participation in the Japanese market } \\
\hline & 4.3 & 1.5 & 5.6 & 10.4 & 16.8 & 23.1 & 59.6 & 58.2 & 13.0 & 6.7 \\
\hline \multicolumn{11}{|c|}{ intend to discourage Japanese scientists from selling their technology to US firms } \\
\hline & 14.9 & 4.5 & 49.1 & 35.1 & 29.2 & 23.9 & 5.0 & 30.6 & 1.2 & 6.0 \\
\hline \multicolumn{11}{|c|}{ gyy to US firms } \\
\hline & 16.8 & 6.0 & 46.0 & 35.8 & 28.0 & 25.4 & 6.8 & 28.4 & 1.9 & 4.5 \\
\hline
\end{tabular}

Journal of Consumer Marketing, Vol 20, No. 6 (2003): pg. 526-535. DOI. This article is @ Emerald and permission has been granted for this version to appear in e-Publications@Marquette. Emerald does not grant permission for this article to be further copied/distributed or hosted elsewhere without the express permission from Emerald. 